\title{
Magazine and Repeating Rifles
}

\section{Captain Walter H. James F.G.S., lato R.E}

To cite this article: Captain Walter H. James F.G.S., lato R.E (1887) Magazine and Repeating Rifles, Royal United Services Institution. Journal, 31:138, 135-161, DOI: $10.1080 / 03071848709416409$

To link to this article: http://dx.doi.org/10.1080/03071848709416409

曲 Published online: 11 Sep 2009.

Submit your article to this journal $\pi$

Џ Article views: 6

Q View related articles $\asymp$ 
Fridar, Febraary 25, 1887.

alajor-General E. H. CliVE, lato Grenadier Guards, Commandant Staff College, in the Chair.

\section{MAGAZINE AND REPEATING RIFLES.}

\section{By Captain Walrer. H. JAstes, F.G.S., lato R.E.}

Iv response to the invitation of tho Council of this Institution I hare undertaken to las before you a bricf summary of the present state of this guestion, the most inportant ono which now demands a solutiou from our military anthorities.

- What is it wo seck to obtain from tho magnzino or repeating rille? Surcly the rapidity with which a good form of single-loader can be fired will suffice. With tho Soper rifle forty-thrco wellaimed shots havo been fircd in a minate, and what more cari bi desired or required in war?

This argument, though usually brought forwart as a reason ngninst the introduction of repeaters, does not really deal with the true reason for their adoption. In a lectare I gavo in this thentro seren years ago, I said, "Tho futuro undoubtedly lies with repeating rilles. Tho advantage of this form of weapon is that it enables a sudden shower of bullets to bo poured in at a momeut when increased intensity of fire will decido the victory." 1

This sudden intensity, this conrcrsion of the shower of ballets into a blinding rain, is to be obtained from the magazine riflo alone. It is for this gain that wo face tho additional complication due to the repeating action, it is for this great quality that the nations of Europe aro spending millions of moncy in the re-armament of their infantry, and that we too mast follow their example.

No brecch action, however rapid, can give the same rapidity so long is tho magazine supply lasts. In a properly constructed magazine rifle the time taken to press the cartridge into tho barrel is climinatcd. Draming back the action cocks, throws out the old case, brings op a fresh eartridge. Closing the breech pushes the cartridge home, which is thereforo never touched by tho man's hand; he has not to take it from pouch to tho breccl.

The magazine rillo has ono other advantage, besides that to which I have just alladed, riz., tho moral support which it gives to the soldier, who knows that he has a reserve of porrer constantly nt liand. No single-londer can givo that confidenco which a man feels who has five or more slots at his instant command.

1 Tol. zxir, p. 3s.t. 
A repenting rifle is of adrintago both on the offensire aud defensive. Troops, whether acting on the one or the other, liove to pass through that supreme moment when the combat trembles in the balance, and to both aliko the special quality of the magazine arm is of the highest importance. Conceive for a moment two lines liolding one another in close action, ono is suddenly enabled to quintaplo its fire-rate, what will be the fato of the other? At times when surprise is of moment, such as connter-attacks, it is also of the utmost value. To scntries, to small bodies of men acting by themselres, such as reconnoitring partics of cavnlrs, the use of a repeater is of the greatest assistance.

I do not propose to occupy soar time with instances of the use of theso weapons, becauso the types which have been employed in former wars are now quite obsolete; but sou are doubtless aware that they were used with considerable effect both in tho American Ciril War and in tho Russo-Turbish. In the former it was said that one man armed with the Spencer ${ }^{1}$ was equal to fro with the ordinary muzzle-loader. In the latter the IVinchesterl did good serrice to tho Turks, who not only armed thcir cavalry with it, but on occasions their infantry also for the close defence of works, ns at Plerna. I propose to take it for granted that the magnzino riflo is to bo introduecd for the reasons $I$ hare giren abore, and to esamine briefly how wo should use it.

To anticipate a little, allow me to assumo that wo have a rreapon which holds five or more cartridges in tho magazine, that the latter can be ensily loaded, and that the rifle can be used as a single-loader.

Under ordinary circumstances the rules of fire discipline will remain the samo as Leretofore. Firo should be by rolless alone, the frequency of which will depend on the range and ubject, but on the offensive, the final rush should be prepared by the uso of the magazine which should be relonded the moment the position is carried. On tho defensire, tho magazino maj be similarly emplosed, bni possibly a littlo more often and carlicr. For instance, at the adrancing troops during their rushes, when they are so much more visible and form so much better targets than when lying dorn to fire. The firo during theso transitory moments should be intensified because good results mas be obtained from it. In fact ro may say gencrally that citber on the otfensire or defensiro tho magazine is chiefly for tho close combat, though occasionally it may be used at longer ranges. Should it ever bo employed for real long-range fire? Rarely. Forit would probably givo rise to a great expeuditure of ammunition without correspondingly udequato results. Against favourablo targets which from their nature are exposed only for a short time to fire it may be made use of. For crample, against masses of infantrs, the staff of tho enemy, caralry, or artillery unlimbering. But it should chiefly be reserred for tho decisive stage, when its proper employment may decide the issue.

ivill the introduction of repeaters incrense tho expendituro of aminuuition? To a certain cxtent jes. Henco it is highly desirable

I Spccincns of both Spencer and Winchester carbines are in tho 3ruscum. 
to lighten the cartridge. To this I shall allude further on. But as a practical fact tho increased cxpenditure of ammunition is not so mach due to the anagazine rifle, which, if its employment where limited to onc or two moments in a fight, would not grently increaso tho namber of rounds fired. Rather is it due to tho fict to which I have before dramn jour attention in this Institation, in the first instance nino years ngo, ${ }^{1}$ that having rifles of long range it would be rery. foolish to limit their employment to short distauces. Tho school of fire is gradually gaining the day, to it belongs tho future, and I look forward to the now not far distunt day when it will be aniversally acknowledged in lingland as it is on the Continent to a great extent now, that in the proper ase of long-range fire, in tho adequate training of the men to pour in closely delivered showers of lead from distances up to 1,500 jards or orer, lies the path to military pre-cmincnce. To this training the magazine rifle forms the proper complement. Armed with it the duly trained soldier possesses the power of multiplying his firo enormously at close range or increasing its rolumo at long ranges when uccessary. Such weapons requiro careful training both of the Oflicers and men, frequent practico in their usc, and careful working out of the problems they give rise to.

How nre you to carry the increased number of rounds the soldier weust have? Ho cannot carry bejond a certain weight, and that weiglt must in the fature consist rery largely of cartridges, his hit nust be carried for him, the regimental supply of ammunition nust be increased until each man at tho moment of battlo has 100 rounds on him, and at least 40 to 50 in the regrimental snpply. Is it possiblo under modern fire to send cartridges to the fighting line? I doubt it: far better at the lasi moment beforo entering an action serve ont an additional supply fairly sufticient for tho fight, and to regard sending more into the firing line as nn exccptional circumstance.

So far for the tactical, and now for the techuical considerations.

It is, I think, desirnblo that I should gire jou a short account of tho present state of the question in European armies.

$\Lambda s$ usual, in all military reforns in the van of progress stands Germans. Immediately after the war of 1870-71 the experiments which had been began before it broke out were again taken up and resulted in the Mauser rille, kuown officially as Ilodel 71 from tho date at which the pattern was definitely decided on. This rifle now lies on the table for jour inspection.?

$\Lambda$ few ycars after endeavours were made to increase the rapidity of fire, and for a tine it seemed probable that tho Löwo magazine mould be adopted. But its clumsiness prerented its introduction, and I feel sure when $I$ tell sou that this is the article in question, fig. 1 , Plate IV, sou will agree with tho German military authoritics.

Besides, all such contrivances aro admissions of the necessity of a repenter, and must bo regnrded as clumsy makeshifts permissiblo only as temporary expedients. The question then bad to be definitely

\footnotetext{
1 Sco rol. xxii, p. 893, et seq., "Jfuxketry Instruction and Long Range Infantrg Fire."

I specimen is in tlie Mluscum.
} 
answered-Repcater or no repeater? In Germany, as usual, common sense carried tho day, and after trying varions forms, tho Mauscrmagazino rifle, which I haro here, was definitely adoptcd. It is, I beliore, now in the hands of fro army corps, aud before the summer the whole German Army will bo furnished with it.

Its principal dimensions are given in Table $\mathrm{A}$.

It can be used either as a single-loader or a magazino weapon. The magazine is placed under the barrel and holds cight cartridges, these with one in the elerator and one in tho barrel nale ten in all. There is nothing particularly worth drawing jour attention to in the constraction of the lock or inagazino system. To shut off the magazinc, open tho brecch and push tho small arm $a$, figs. 1, 2, and 3, Plate III, on the left side of the rifo forward; this moves tho other end of the cam of which it forms a part forward into tho underneath portion of the clerator $b$, and thus fixes it so that it docs not fall down when tho magaziue is closed.

Tho Mauser repenter, 31. 71/84, fircs tho samo cartridgo as tho MIauser rifle, $\lambda I / 71$, but latterly experiments haro been mado with an improrad one containing $891 \mathrm{l}$ grs. of compressed powder and a steelcorcred lead bullet. IVith this cartridgo tho muzzlo rclocity is greater, the penctration considerably more, and the trajectory much flattened, especially at closo ranges. This will bo seen by reference to the Table $A$ and to Plate $V$, which shows tho trajectors.

In Franco no definite solution as to tho arm to bo adopted has as yet been come to. It scems, howorer, probable that the arm will be tho Lebel, which is called after tho mane of its inrentor, a Colonel in the French Service. I nm anablo to give you any definite information about it bojond the fact that its calibre is $78 \mathrm{~mm}$. or $0.307 \mathrm{in}$., and that the magazino nnder the barrel holds cight cartridges. Later on I shall deal with this question of small calibres, and will not therefore further discuss it now. For some Jears past, howerer, the French Nary has been armed with the Kropatscheck repeater, of which this is a speciucn and which is shown you in fig. 4 , Plate III. It differs not materially from tho Mlauser except in being a littlo moro complicated, and the chicf points with regard to it aro given in Table A. For detailed account of tho reasons which led to its introduction $I$ will rofer to an article I contribated to tho Journal of the Institation some eight years since, vol. xxir, p. 38t, ct seq.

Austrin has definitely adopted tho Manulicher rille, figs. 5,6 , Plate III. This rifle presents screral peculiarities vortly of notice. In the first place the bolt is withdrawn by a straight backward motion, which renders it much quicker than one in which it is necessary to make a turn as in most bolt rifles, and herice it can ló morked without taking it down from tho shoulder. Tho cartridges aro carried packed in tin frames containing firc, fig. 7, which are placed in the caso placed under the bolt-chnmber, and whence they automatically full when empty. The cartridges are carried packed in these frames, two bcing wrapped round with paper, and thus issacd to the soldier. The frames weigh 385 grains each, i.c., roughly the weight of a ballet, and cost less than a half penny to mannfacturc. When these cases aro 
MAGAZINE AND REPEATING RIFLES.

\begin{tabular}{|c|c|}
\hline & 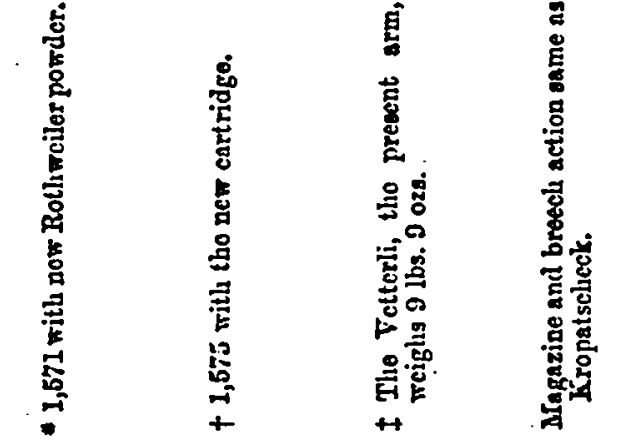 \\
\hline 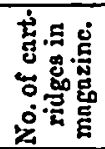 & 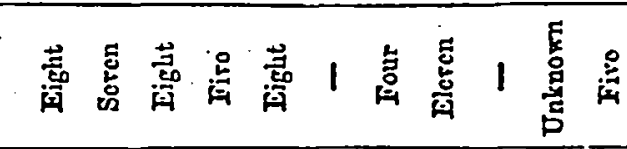 \\
\hline 这 & 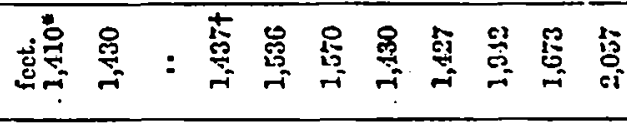 \\
\hline$s i=$ & 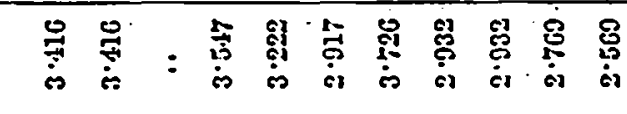 \\
\hline 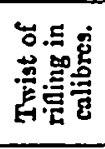 & 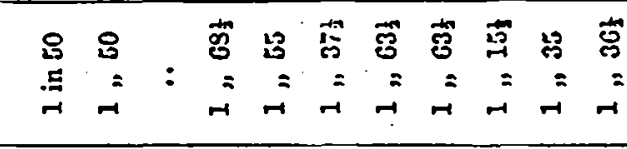 \\
\hline 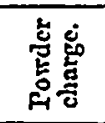 & 暨太 \\
\hline 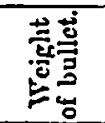 & 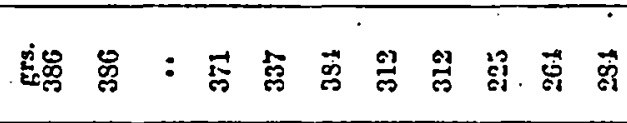 \\
\hline है & 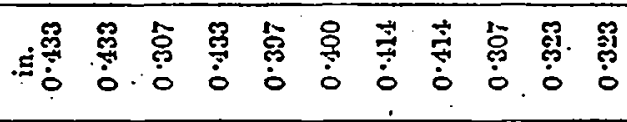 \\
\hline 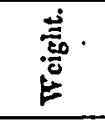 & 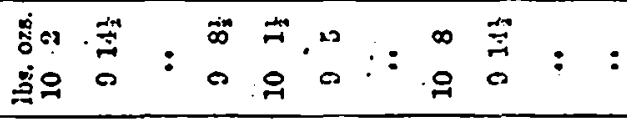 \\
\hline 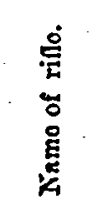 & 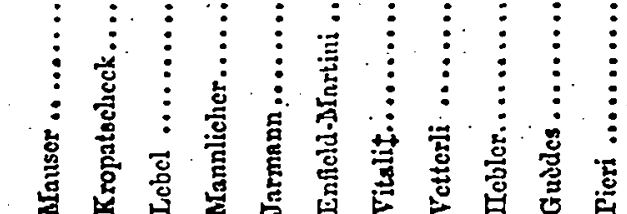 \\
\hline
\end{tabular}


placed in the rille, e.g., when arranged for magazine action, it canuot be fired as a singlo loader, although there is no reason why more than one round should bo fircd. Tho cartridge used is tho sano as that cmplojed for the Werudl rifle, the weapon hitherto in aso in tho Austro-Hungarian Army. Experiments are, howerer, being mado with an improved cartridgo giving a higher initial relocity.

In Iialy, experiments hare been conducted for some years past, and it has been finally determined to alter the Vetterli rifle, which is an ordinary form of bolt-gun, in accordance with tho system bnown as the Vitali. A magazine is fixed in a central position under the boltchamber, in front of the trigger-gunrd, in which four cartridges packed in a special cardboard box aro pushed from abore. I hare not been ablo to get a specimen of this weinon, but, so far as I am informed, it, like the. Mannlicher, cannot be used as a single-loader when the cartridges aro placed in the macrazinc. This change is arowedly only a temporary expedient pending the introduction of an improred and probably snaller bore rific. It only costs 11 franes per. piece.

Russia has, like other nations, experimented with repeating rifles, but has not jet definitely settled ou a pattern. Sho has introduced Frans' repeater into her navy-a specimen of which system is in the rnuseuin. It is distinguished from all others by the large number of cartridges it holds, viz., thirty-five, which are placed in the butt. I do not think, howerer, it is likely to be introduced into tho army. In the meantime, it is stated in the "l'imes" of the 19th Februnry that a form of attachablo magazinc has been introduced for the Berdan rifle, which holds threo cartridges, and which can be fitted with a metal caso containing fre others, or eight in all, and that this apparatns, whaterer it mas be, can be fised in less than ten minutes to tho rifle.

Sweden has for somo time had the Jarmann rifle. I am sorry I am not ablo to show you a specimen of this arm with the magazine under the barrel, as in the Swedish regulation arm, but it does not possess any special peculiarities or adrantages. Its action is shown in fig. 8, Plate III.

Switzerland has for some jears had the Vetterli rifle, fig. 2, Plate IV, which has a rim-firo cartridge, and is scarcely now on the first rank of weapons. Portugal has recentls adopted the Guedes riflo with tho Kropatscheck breech and repeating action. 'This rifle is distinguished from all the others I hare mentioned by its small bore and high initial velocity.

It will be secn, therefore, that crerg nation has cither definitely adopted, or is experimenting with a viow to deciding on somo form of magazine. We, too, hare, I beliere, mado up our minds to follow suit, and I venturo to think our authorities aro to bo congratulated on haring determined to do so rather than to re-arm our infantry Tith an ordinary brecch-loader, as was proposed but six months ago.

1 have here, by the kindness of tho Secretary of State for IVar, two rifles, the one known as tho Lee Burton, the other as the Improred Lee. Of each of these rifles a limited number will be mannfnetured 
and issued to the Army for trial, but no pattern of magazino rifo has ns jet been definitcly settled on for the fature armament of our troops.

It is, of conrse, nataral that this unircrsal determination to change the armament of Emropean armies should have given a great stimulus to inrentors, and I suppose there is hardly a day that does not bring forth a fresh weapon. I propose, tberefore, to discuss bricfly the lines of progress in riflo reform, bearing in mind that what we requiro is a soldier's weapon, not a match rifle.

'The frst point to consider is what do wo want onr riflo to do? To shoot well and closely at rauges up to 1,500 or 2,000 5ards; to hare a flat trajectory within what. I may describo as the decisivo fighting zone, say 600 jards. These tro conditions, other conditions being equal, require-

$$
\begin{aligned}
& \text { A, a high proportion of weight to area of bullet (i.e., } \frac{d^{2}}{w} \text { as near } \\
& \text { unity as possible). } \\
& \text { B, a high mazzlo rclocity. }
\end{aligned}
$$

The recoil depends apon tho weight of the bullet, the weight of the rifle, and the amount of powder. 'To fulfil $A$ without unduly increasing recoil and maintaining $\mathbb{B}$ as high as possible, it is necessary to bare at long light bullet, in which the proportion $\frac{d^{2}}{w}$ is bept low, i.c., a small bore is a necessity. If we could use 500 to 600 grains of lead as is done in somo match rifles, wo could have a bore of $0.45 \mathrm{inch}$, but then the charge of powder necessary to obtain a flat trajectory would be so Jargo and involve so heary a weapon that the soldier could not use it; for the fircarm must not be heavier than 9 to $9 \frac{1}{2}$ lbs. 'Theso facts hare indaced many experiments in Fingland and also abroad with a vicw to nscertain whether it was possiblo to design ono which should combine as much as possible the qualitics of the express and long-rauge ritle. Among others who have followed out this line of rescarch I mas mention Lientenant-Colonel Bode in Germany, Major Rabin and Professor Hebler, formerly an artillery Officer, in Switzerland. The last-named has published a work called "Das Kleinste Kaliber oder das Znkünftigo Infanteriegewehr," which I can strongly recommend to the attention of all who take an interest in this subject. The two latter gentlemen have for somo years carried on experiments with small-boro rifles, and both alike directed their cndearours to find out a projectile which should take the grooves well, not lead them, and set not wear the barrel. With rerg long projectiles driven at high velocities through a quick twist, there is tho danger that the projectile, if too soft, will strip ; if too hard, will wear out the barrel. Messrs. Rubin and Hebler both determined that the best form of projectilo was lead covered with a thin shell of harder metal; the former and also Colonel Bodo closo copper; the lntter, stecl. Specimens of both kinds of bullet aro on the tablo (sec Plate $\nabla$ ), but I belicvo I inay fnirly say that the lead corered with stecl is the better of the two, and this projectile, duc in its present form to Herr 
I Jorenz, tho proprictor of the well-known ammunition mannfactory in Karlsruhe, is, I think, destined to play a great part in the future. The advantages elaimed for it are, that it does not lead the grooves or wear tho barrel, while it takes the grooving accurately and has no tendency to strip. Noreover, it renders unnecessary the use of lubricators, and it maintains its form better in penetrating objects than does any projectile of lead. I am indaced to direll on tho Lorenz compound steel-jacket bullet, because of tho attention it has attracted in all foreign countrics, and becanse I beliovo its uso to be necessary if a really small calibre rifle is to be used. It has been largely experimented with in France; it will in all probability bo introduced in the German Army; it has actually been adopted for the new Portugueso rille. I havo here a bullet which has been fircd from the Uebler and one which has been fired from the Ginedes, i.e., the Portuguese rifle. You will obscrve that in cach caso tho thin stecl jacket is not cut, but merely pressed into tho lead, which I should state consists of 97 per cent. lead and 3 per ceut. antimony, and is attached to the stecl by a thin coat of tin. 'Tho clcan close-fit surface of the stecl polishes out tho bore every time and removes fouling, and hence it is unnecessary to use a lubricator, and as the stcel is so thin, it has not half the wearing effect of a really hard lead picket, and, as a practical fact, I may add a Hebler riflo hins fired 1,500 rounds without showing tho slightest degradation. Latterly the steel shells have been nickel-plated, which still further improves their slooting and docs awny with any liability to rust.

Hero are also Martini-Henzy bullets and the new Jiauser bullet. With regard to the latter I may say that the compound steel projectilo penctrated through two blocks of bech wood, $3 \frac{1}{2}$ inches thick, and cleren planks of deal, 1 inch thick, when fired with tho service chargo of 75 grs., whereas the old form of lead bullet barely penetrated through $3 \frac{1}{2}$ inches of becel.

Tablo $\bar{B}$ gives a few details of some experiments conducted at Enficld on the 12th Juls; 1886.

TABLE $B$.

\begin{tabular}{|c|c|c|c|c|}
\hline \multirow{2}{*}{$\begin{array}{l}\text { Distinguish- } \\
\text { ing letter. }\end{array}$} & \multirow{2}{*}{ Ride. } & \multirow{2}{*}{ Powder charge. } & \multicolumn{2}{|r|}{ Bullct. } \\
\hline & & & Wcight. & Naturc. \\
\hline $\begin{array}{l}\mathbf{A} \\
\mathbf{B} \\
\mathbf{C} \\
\mathbf{D} \\
\mathbf{l}\end{array}$ & $\begin{array}{l}\text { Enficld-Jrartini } \\
\text { do. } \\
\text { MInuscr } M / 71 \\
\text { do. } \\
\text { do. }\end{array}$ & $\begin{array}{l}85 \text { grs. R.F.G. } \\
\text { do. } \\
76 \text { grs. } \\
76 \text { do. } \\
58 \frac{1}{2} \text { do. compres } ₹ e d\end{array}$ & $\begin{array}{l}\text { grs. } \\
354 \\
284 \\
3 S 6 \\
396 \\
356\end{array}$ & $\begin{array}{l}\text { Lard lead. } \\
\text { do. } \\
\text { soit lead. } \\
\text { do. } \\
\text { stcel compound. }\end{array}$ \\
\hline
\end{tabular}




\begin{tabular}{|c|c|c|}
\hline Target. & $\begin{array}{l}\text { Riflo } \\
\text { reference } \\
\text { letter. }\end{array}$ & Penctration. \\
\hline $\begin{array}{l}\text { Sand .......................... } \\
\begin{array}{l}\text { Tro bech blocks, cach } 3 \text { incles } \\
\text { thick, with deal planks behind, } \\
1 \frac{1}{2} \text { inclecs apart and } 1 \text { inch thick }\end{array}\end{array}$ & $\begin{array}{l}\text { A } \\
B \\
\text { A } \\
\text { B } \\
\text { C } \\
\text { D } \\
\text { E }\end{array}$ & $\begin{array}{l}0.75 \text { inclics. } \\
10.5 \text { inches. } \\
1 \text { block. } \\
2 \text { blocks and } 6 \text { planks. } \\
1 \text { block. } \\
2 \text { blocks and } 12 \text { deals. } \\
\text { do. do. }\end{array}$ \\
\hline
\end{tabular}

The results speak for themselres, and show clearly that the stecl compound shot has a higher penetration than the others. I am of course arrare that a rery hard picket may be made which will penetrate as well as the stecl compound ballet, bnt such $\Omega$ bullet cannot bo fircd out of any riflc continuously without ruining tho rifling. Such projectiles must be lnoked on as experimental togs, nnd not as intended for practical use. An extensiro series of experiments conducted by Dr. r. Beck, and which aro fully described in his book, show that in trarersing tho body, whether of man or animals, it, is much less liable to deformation.

Many of you will donbtless remember that in the interesting lecturo given by Colonel Arbuthnot on the Eufield-Martini rifle he stated that tho reason why the calibre of 0.4 had becn chosen was that with smaller bores the shooting was not so regular. This rior docs not agrec with that held on tho Continent, for although Germany and Austria hare lept to their present bores of 0.433 iuch for reasons of economy and rapidity of transformation, because the existing barrels can be used for the new repeater, it is by no means certain thint tho former at any rate will not eventually adopt a smaller bore of 7 to $8 \mathrm{~mm}$, while it is almost certain that France will do so. I know that in Anstria cconomy alono prevented tho adoption of a calibre of about $8 \mathrm{~mm}$.

In Fingland we aro about to adopt a magazino rilic. I shocld, spcaking for mysclf, like to sco experiments conducted under pnblic conditions with bores smaller than $0 \%$. It must not bo forgotien that $n$ Government rifle designer has not the free hand a private ono has. The latter can do as be likes with regard to cartridge case, porder, and bullets. Tho Government oficial has to consult two other Departments, who may not agree in his riews. To hare a riflo which shall fulfil the most necessary quality in a good military nrm, riz., flat trajector's, a small bore is an absolute necessity. To illust rato what I mean, look nt the trajectories in Plate $V . A$ is tho old Snider, B the Martini-Henry, $C$ tho Fufield-MIartiui, D a rife of 0.35 in. calibre, $\mathbf{E}$ and $\mathrm{F}^{\prime}$ of 0.32 and 0.30 in. respectirely.

In the lorrest the $\frac{d^{2}}{w}=2.093$, in the highest 4.855 , and the calibres corresponding are shomn in the Table $\mathbf{C}$. 
TABIsE C.

\begin{tabular}{|c|c|c|c|c|}
\hline \multirow{2}{*}{$\begin{array}{l}\text { Referenco } \\
\text { Ietter. }\end{array}$} & \multicolumn{2}{|c|}{ Bullet. } & \multirow{2}{*}{$\frac{d t}{10}$} & \multirow{2}{*}{$\begin{array}{l}\text { Mrunzle } \\
\text { relocity. }\end{array}$} \\
\hline & Wcight. & Diameter. & & \\
\hline $\begin{array}{l}\mathbf{A} \\
\mathbf{A} \\
\mathbf{B} \\
\mathbf{O} \\
\mathbf{D} \\
\mathbf{F} \\
\mathbf{5}\end{array}$ & $\begin{array}{l}\text { grs. } \\
450 \\
450 \\
384 \\
300 \\
300 \\
300\end{array}$ & $\begin{array}{l}\text { ins. } \\
0 \cdot 577 \\
0 \cdot 450 \\
0 \cdot 400 \\
0 \cdot 350 \\
0 \cdot 320 \\
0 \cdot 300\end{array}$ & $\begin{array}{l}4 \cdot 855 \\
2 \cdot 953 \\
2 \cdot 917 \\
2 \cdot 853 \\
2 \cdot 331 \\
2 \cdot 093\end{array}$ & $\begin{array}{l}1,210 \\
1,315 \\
1,570 \\
1,720 \\
1,700 \\
1,700\end{array}$ \\
\hline
\end{tabular}

The highest points of the trajectories of bullets $E$ and $F$ for a range of 1,000 Jards are : for $E, 31 \cdot 09$; for $\mathrm{F}, 28 \cdot 70$.

Spenking in this Institution some seren sears ago, in a lecturo which I gave on "Nodern Fire," I predicted that we should go to much smaller bores, and suggested 0.38 inch. I also prophesied that tho repeater was the weapon of tho future. I had hoped that we might hare taken the lead in these adrances, and not havo followed respectfully in the wake of forcigu nations. But I am glad to find that at last we are to have a magazine weapon, and I sincerely trust it will be the best that the most open competition can produce. The Officers selected to decide on this, the most important question of the day, will of course be chosen for their practical knowledgo and their acquaintance with tho sabject, and $I$ am sure wo shall leave the choico with great confidence to them. It seems to me, however, that before finally deciding on tho calibre fnrther trinls should bo made of smallbore rifles. Personally, I think that with our present experience a rifle of 0.32 bore with a ballet weighing $336 \mathrm{grs}$, and a powder charge of about 90 to $100 \mathrm{grs}$., would be a desirable combination.

There is ono objection which is usually put forrward against smallbores, viz., that the bullets fired from them aro much more affected by a side wind. Now, in the first place, I. wonld point out that the wind does not nlways blow across the trinjectory, and if it do so, and admitting that the light long bullet is more affected than a short heavy one, if this idea is to be carried to its logical conclusion it would necessitate a retarn to round bullets which aro cqually reighted on all sides. Bat as a practical fact, when this objection is raised a rery inportant consideration is completely lost sight of, riz., that on the field of battle it is the mass fire of numbers, not the aimed firo of individuals, that has to be taken into considerntion, aud that therefore lateral deriation, considering that we aim at broad targets of little depth, is of far less moment than is fiatness of trajectory. This latter is tho grent object to be attained in a military riflc, aud is of far more importance to tho soldier than lateral error, howerer much that mas be objectionable to the match shooter. Flat 
trajectory, i.e., a long depth of shot-swept space, we must have, aud to it we must sacrifice, if nccessary, some less needed qualities in the rifle. Morcover, in these days when the good old superstition that having a lonig-range rifle, we should endeavour to prerent it being used until we come within the mages at which alone the feebler weapons of our forefathers were effective is rapidly dying out, and longrange fre is now universally adinitted, and infautry tactics based on its employment. Long-range fire, breech-loading rifles, magazine arms, all represent as many steps aloug the path of increasing expenditure of ammonition. The soldier must carry more cartridges; he can only carry a certain weight, to get more rounds of ammunition out of that weight it must be further snbdirided, therefore the cartridgo must weigh less, i.e, the bullet, must weigh less, to give a flat trajectory $\frac{d^{2}}{20}$ must be small; - in short, a small bore is the logical ontconis of modern requirements in an infantry arm.

Thero is only ono other point to which I shall allade, viz., the objection to small-bores sometimes put forward, viz., that they lack stopping power. Stopping a man depeuds largely on where you hit him. $A$ bitclien poler which grazcs an $\Lambda$ rab's ribs will not stop hirn so well as a 50-grain bullet through his head, or through the lower half of his trunk. I wish those gentlemen who still hold these opinions would kindly look nt the medical records of the Franco-German War. Iset them read Sir WVilliam MI'Cormac's "Work done under the Red Cross," Dr. Esmarch's work on Military Surgers, Dr. Beck's Experiments with Small-bore Bullets, and they will find that rapid moving long ballets with augular velocity cnongh to leep them poiut folemost, will, striking half way down the femar, go through and split it up into the hip-joint, involving amputation at that point. I remember when express rifles wero first introdnced wo were told they were not as good as the old round bullet: who sass so now? It may tabe a ton of lead to kill a man, but don't ask the soldier to fire it all at once, or the number of rounds he can carry will be rery much limited.

Iraving determined upon the ballet, the next steps aro the riaing and the powder. Tho question of rifling has been so fully threshed out. that I need hardly allude to it. Nearly all rifles hare; nomadays, broad, shallow groores and narrow lands; fig. $l$, Plato $\nabla$, shows you the form emploged by Professor Hebler. The rifling is, you will see, about 5000 ths (exactly 0.0052 in.) of au inch deep, which is an ordinars amount. 'The lands are 0.0195 in. wide, the grooves six in number. Tuble $D$ gires some idea of the accurncy of the reapon in question, while the diagram of trajectories shows that for 600 jards range, the ground would be practically swept from the muzzlo to 650 rards. 
TABt,. D.

\begin{tabular}{|c|c|c|}
\hline \multicolumn{2}{|c|}{ Range. } & \multirow{2}{*}{$\begin{array}{l}\text { Radius of circle in fect contain- } \\
\text { iug half the sliots. }\end{array}$} \\
\hline AIctres. & Fards. & \\
\hline 500 & 517 & 0.852 \\
\hline 1000 & 1093 & $2 \cdot 625$ \\
\hline 1500 & 1610 & 6.851 \\
\hline 2000 & $218 i$ & $13 \cdot 012$ \\
\hline
\end{tabular}

As to the powiler. Great strides have been made in the last few years in the manufactnro of guupowder. The sharp almost detonating action of the old form has given place to slower burning compositions, which gire cqual velocitics with less pressures. In small-bore rifles, where tho number of expaysious allowed to the chinrge owing to the great length of tho barrel is large, vers slow burning powders can be used. With such powders tho recoil becomes moro a push than a blow, and is consequently less felt. Greater charges can therefore be fircd.

On the Continent a largo number of experiments lanse been made with compressed powder, and it secms destined to como into universal use, becauso with it tho charge can be made more uniforn, and bence more uniform velocities obtained. Here is a German cartridge loaded in this manner, and Hobler and otlier esperineuters have emploged it too. Compressed powder has ono great adrantage, riz., it occupies less space for the same weight, and hence gives a better sliaped cartridge. Witle regard to this latter point, viz., the form of the cartridge case, with large cliarges and small-bore bullets, the caso becomes rery "bottled;" this is clearly shom in the caso of the Martini-Henry and Hebler cases, sce Plato $\nabla$. It scems to me that tho truncated cone shape is a far better onc, such as I now show, sec No. 2 cartridge, Plate $\nabla$, which is intended for the Enfield-Martini rifle. This case is much less likely to stick, as it has not got the long narrow neck, and, morcorer, when onco it is started it cannot do so, as the surfaces of the cartridge and chamber come apart. I am informed by a large manufacturer of ammunition that this form is no more difficult to make than the bottle shape.

I think, then, from what I hare said, we may fairly make three deductions. lirst, that we should havo a rery much smaller boro than hitherto cmplosed, probably between 0.36 and 0.32 , but as near the latter as possible, that $\frac{d}{w}$ must be low to gire with a relatirely large powder charge a rery high relocity. Secondly, wo must seck 
for a slow burning powder, which should be used in a compressed form. Thirdls, that we should use is conoidal cartridge.

Here let me draw sour attention to the desirability of using smoke. less powder. $A$ considerable amount of attention las been given to this question on the Continent, and I need bardly point out to you the cnormous adrantage to be gained from it. Advancing lines would no longer be indicated by their smolie, the defenders of a positiou would no more bo compelled to ccase fire to obtain a viow of the gronnd in front of them. I an sorry that I cannot givo jou details of tho composition of any of these experimental forms of powder, but such matters are, as you are aware, always bepi a profound secret. I am aware, howerer, that tho Freuch have lately been trying a white powder, which is said to have given astonishing velocities, though what it is made of $I$ do not know.

The next point we bave to consider is the magazine, i.e., tho reservoir from which wo draw our stream of continuous fire.

All forms of magazine can, so far as their position is concerned, bo divided into four classes :

1. In tbe butt.

2. Under the barrel.

3. Orer the barrel.

4. Under tho bicech.

No nation has the first.named, cxcept Russia, in tho Erans repeater. Tho sccond has been adopted in France (Kropatscheck), Germany (Alauser), Switzerland (Vetterli), Sweden (Jarmann), Portugal (Kropatscheck). It lass tho adractago of giving room for a number of cartridges, but the vers great clisad vantage, which it shares with first position, of being difficult to load. Moreorer, the balance of the ritlo is altered each timo a shot is fired. The German ritio is very funlty in this respect, and is, when the magnzine is filled, an cxtremely awkward and ill-balancel weapon, besides bcing vers heavy, weighing 11 lbs. Orer tho barrel is cxtrcmely arkward for the soldier, and in the ense of those weripons which have tho magazine on ono side, is bad for aiming, cspecially whien the sun is shining from the opposito side to that on which it is tixcd. Thesc thrco forms of rifle, viz., the Burton (see Plate XII, vol. xxi), tho Lce Barton, and tho Owen Jones, fig. 3, Plato IV, hare such magazines. Uuder. neath tho breech, is, on the wliole, the best. The rifle is more compact and far better balanced. Its sole disidvantago is the fact that it is difficalt to arrango for more than about fivo cartridges. These rifles, viz., tho Mannlicher, figs.' 5,6 , Plato III, the Schulhof, figs. 4, 5, 6, Plato $\nabla$, the Pieri, and tho Lee, and tho Improved Lee, all havo this form of magazine. All hold fire cartridges except the Schulhof, which will take ten arranged round a dium like a revolver.

Should the magazine be attacliable or fised, i.c., fore part of tiro rifle? I-think the latter plan to bo preferable, becauso thero is theu no chance of its being lost at the moment. it is wanted, and if a 
number of loose magazines are to be carried, or the cartridges haro to be packed in special attachable frames, the armament becomes more costly, and a lot of unnecessary weight has to bn carried.

The theory, one I think essentially of peace, that tho soldier can cariy one or two magazines which be can affx just at the most. critical moment of a combat, leares out of consideration tho disturbing elements of the fight, which would in all probability render it very problematical whether all the magazines would be forthcoming, and if thes were rould certainly interfere with tho fixing of a largo proportion of them. No great Furopenn nation proposes to adopt this system, such as you havo here in the first form of the Lco rifle.

In tho nnder-barrel forms of magnzine rifles, it is not proposed to load the rifle during the heat of an action. It wonld be filled beforo going under fire, cut off from neting, and only brought into use at the supreme moment. In rifies like the Mannlicher, the Lee, tho Improved Lee, the Pieri, the cartridges can bo very casily replaced, and consequently a inore prolonged intenso fire be giren than whero this cannot be donc, as in the nnder-barrel type. I may instance as a proof of this, that the firo shots from the Mannlicher can bo fired in $3 \frac{1}{2}$ seconds, aud that 46 have bcen fircd in ono minutc, i.e., tho tho framo has been six times replaced. If the magazino holds ten rounds, as in the Schnlhof, the fire will undoubtedly at the supreme moment be moro intense, but it cannot bo bept up at tho samo rate as when set after set can be fired, as in such rifles as the Pieri, Mlannlicher, \&c. Probably, therefore, on the whole, the latter is befter, but nothing but actual cxperiment in large numbers plaeed in the hands of infantry soldiers can really decide this point.

There can be no doabt that it is desirable to have a magazino holding a fairly largo number of rounds, bat too many would so increase the weight of the rifle as to strain the soldier far bejond his powers. This was found to be the case in some I'rench experiments, in which the cxtra weight carricd, oring to the cartridges in the magazine, took so mucli ont of the men that they did not fire as effectirely as those armed with a single-loader. This then is ono great adrantage possessed by thoso rilles which hold only a comparatively small uumber, bat in which the loading of the magazine is only the work of a few seconds, such as the Mannlicher, tho Picri, and the Lee. Tho londing process in the Schnlhof is very quick, and can be made quicker by packing the cartridges in special frames.

What action shall our riflo have? The much-abused bolt is of course a necessity, indecd of all the weapons $I$ hare herc one alone, the Jones, is a block gun; shall it be ono which pulls simply straight, bachwards and forwards, or ono which require a turn as well? I would point out that to fire without remoral from the shoulder the former is a practical necessity, as with the latter form of action the nim would be too much distarbed, and the tristing motiou required to open the breech is extremely difficult to carrs out when leeping the rifle at the present. 'I'ho Sustrian (Mannlicher) and the Schulhof hare bolts of this description, the Jones lias a strnight pall back too, all the others that I hare here require the double motion. I do not 
think that there can be any doubt that the one simple motion is the better.

I now propose to call your attention to tho different rilles to which I havo just alluded :-

The Jones rifle has a simple pallback nction worked by drawbar, $a$, just behiud the trigger guard. The breech action is a falling block one, and tho magazine, which holds fivo cartridges, is on tho side. Pulling back the drawbar depresses the block, ejects the exploded cartridge, pushing it forward again brings a cartridgo up from tho magazino into the brecels. This rilo is a very quick one to work. Its chief drawback, though, of conrse, this is only a relatire one, is the large number of parts of which the action consists.

'I'he Schalhof presents screral points worthy of attention. In the first place the cartridges are placed in a dram, $a$, in a central position, fgs. 4, 5, 6, Plate IV, and are brought up one by onc b5 tho backward and forward motion of the brecch bolt. 'The drum can be londed with a single cartridgo or anj number up to the maximum it contains. The action is cxtremely simple, and the bolt is worked by a simple backward and forward motion. Altogether this system appears well worthy of attention and trial on a practical scalc.

'The Pieri is chictly noteworthy for the arrangement by which the cartridges aro fed up ons by one as required, a ratehet being worked by the motion of the brecch bolt, which is of the ordinary Gras construction.

'The Bethel Burton has two special qualities. First of all tho whole brecch mechanism is carefully covered from dast; sccondly, the breech bolt is locked by means of an interrupted screr, the motion of wbich in opening materially nids the extraction of a tight-fitting cartridge. The magazine, which is on the side, acts by gravity alone. This was described by Licut.-Colonel Fosbery in his lecture hero four years agro.

The Winchester, a tried and proved weapon which has dono good service in the field, I need hardly describe. A specimen is in the Museum.

In conclading this lecture, I can only say that my endcarour has been to put before you, ns fairly as I could, the preseut stato of the ritle question, to describo the rarious systems now.adopted, or proposed. I could not within tho limits of a lecture go into a mechanical examination of all the systems that have been put forward. I have, therefore, limited myself to type forms, or to thoso which havo actually been introduced into various Scrvices.

The Chairyar : It will be conrenient if, in the diecussion, we confine ourselres to the point that Captain James has brought out so strongly, namely, that what re are now-trying to arrire at is the best ride for the British soldier. The question of eupplyillg magazine arus to our troope bas been a good deal debated of latc, and I hope tlan any gentleman who is good cnougis to nddress us will confine his rejnarks to what I may call the military points, and not go into purcls meclanical matters of construction which we cannot follow out.

Major-Geocral BrıT, C.B. : MIr. Chairman and gentlcmen, the question whether or not we are to haro repesting rifes appears to hare been ectled, and it is high time, 
I should sny in this nsscmblr, it was seltled. The Committce liaz been a long time orer it, though I do not blame them much, because it is a vers great and an crtremcly difficult question: We hare a rast number of rifles now on fiand, perhaps as many as a million, and the question that thes hare had to deal with has been how to manipulate and nrrango so that the udoption of nuggazino rifles shall not cause the cntirc re-arming of tho British Army. The samo dificulty has occurred rith other nations, asd thoso rifes which $w \mathrm{c}$ sce beforo us aro adaptations nore or less of the burrels that thes had on hand. With regarl to the rifles themselre:, I have cranined nearly all the rifles that arc now before us, and out of that umbucr I hare eclected three ns being out and out the best repenting rilles that hare set been producci. The first one I rould mention is rlant lass beca called the Remington-Lec rifle. The Remington-Iseo is a splendid reapon; it has a marazine underneath which contains six eartridges; it has a beautiful barrel, and is an admirablo meapon, haring this adrantagr, that the Captain of the company can control the magazive fire. Looling at the Kenington-Lec you will ees that the American soldier recorers the arm. at the worl from his. Cintain "JIagazine lond!" It is done in an instant. Then he can also gire the orler "Mregarine unload!" So that be controls the fire of lis company. Whereas if the cartridges are in the barrel of the gun, or in nasgazincs under the cntire control of the soldier, when you once get into action you will find it almost impossible to control the fire of your men. 'Ilbat is most iemportant, because there are trro ricws to take of a ride, the accurate fire question anel the military cflicicuer question, and they are as clistinct as two things can trell be ore from nnother. The Committec now sitting on these rifles contains theoretical men and practical men; the theoretical men nro all for hittin: bulls'-cres at a thuusand sarits; the practical men are for putting a rifle into the hands of the British Eoldier with which he can shoot down his cnemy at distances under 100 jards; these inportant poiuts niust nerer be separated. The trajectorics look rery niee on paper, but to arrire at those trajectories, the rille must be fixed in a rest, because if it is put in the hands of a soldier who is firing, the trajectory entirely depends upon the angle at which he holds the rifle. Therefore for mere figliting purposcs you may takic it for granted, and there are a great many gentlemen here who hare not feen war at Wimbiedon only, but all orce the world, who know this perfectly well, that the real fighting of the soldicr begins at 400 yarls, and finishes within that distauce. Now the Remington-Lce I considered an admirable wcapon until I lookcd at it carcfulls. If jou take the Renington-Lee No. 1, with the m:agazine underncuth, you will find that the epring which attaches that mngazine is just insido the trigger-guard, and if. you touch that uwi wardly or intentionally out dirons the magatzivo between the soldier's fect, and of coursc that defect is fatal anth hills the rille. It bas becn iunproved, I belicrc, and therefore is a better rifle than when I saw it. The nest rife I eclected was the Burton. All these rifles lare the loll action, but tho Burton has this adrantage that it has a closed bolt-action. It hus, lowerer, one great dis:ulinntage, and that is that you hare to fir the magazine on the side of the rille, which is rers awimard and clunsy, and though it has the rery great adrautage that the cartridges drop into their place by graritation, still, I think that a magarine stuck up on $^{-}$the side of the rifle, cither on the right or the left, is a great drawbuct: If Mr. Burton could get rid of that diaiculty, I nw ecrtain that his rile would be one of the finest that we hare seen. I hare also sern tho Mrnuser rife. This rifle weighs 10 lbs. 2 ozs.; it is, howerer, rery bally balanced, and the reason that the Germans hase ndopied it is simply because they wavted to utilizo the riles that thes hasl in their Arms. Ther liave, thercfore, made an aditptation, and hare made the best use of their rincs which they could. The Germans cilery greater weight than the Iinglish soldiers, and more casily, and as a Germa: told me the other das, no: mun in the Gerwam drny would object for one instant to carry the licary Mauscr. There is a great dinl of difference between the weight of thint rifle and that of eome others thiat hare becn mentioned. I consider the inost wonderiul and the clercrest rifle of nll is that by Herr Schulhof of Austria. The Sehulhof riflehas been shown last, but $I$ think it nighlit liare been shown first. It lins got the magaziou unclernenth, it worls with the greatest facilit5, is adnirably made, and tho lock action is remarlably simple; it is a bcautifully balanced rile, though it looks 
large and clumsy, and the stock is wonderfully itaprosed; it has a grooring down the sitc, which eatches your land the moment you take liold of it. Tho wood part corcrs tho rife so complctely that the fire-action does not hurt or hest the liand in ung was. I am quile surpriscl that it lias not takcu the prize 23 far as the $\mathrm{Com}$. mittec las gone. Of course the Cornmittee hare looked into the matter with the greatest possible faimess and care, rnd I hopo that ther will arrice at the hest rifle that has erer been introduced in Furope for the British soldier; that thes will tale the best parts, as they generally do, of the competing rifles put beforo them, and make the most perfict weapon thit lasy erer been proluecl.

Colonel Hore, V.C.: I would ask whether Captain James does not consider that if this $\frac{d^{2}}{s 0}$ were reduced still further below units it would not be an improrement; and, sccondly, whether le could farour us with a sight of any of the recent cutlasses.

Mr. C. Frederice Lowi, Quecr's Westninster R.Y.C.: Mr. Chairman and gentlemen, I will not enter into sny teclunical question about any pattern of bolt or repeativg rille, but I think probably gallint Officers may be interested to learn the rensou wilas for so mans scars our unilitary autloritics rould not loo' at a bolt gun. I believe some twenty jears ago, that while firing a primitire form of bolt rifle, an accident happened to a member of the House of P'cers, and also fourteen or fiftecn years ago ut very awkward accident bappened to a well-knowil slot at Wimbledon, and for those reasons tho militarj authorities will not look at a lolt gun-"Oh, it is a bolt gun, it will not do for Her JIajcsty's Serrice ;" but when nearif erery foreign nation his atloptenl the direct mode of extraction, instead of getting at the head of the curtridge througli a series of lerers, common scuse las at last prerailed. I heard that while o bolt rifle was being tricd for mapidity, is cartridgo hung fire, and csploded when partly extracted, and accorling to official reasoning that was a rery stron: argument why the bolt gun should not be $u$ icel. Of course the same accident nould liare happened with any other clescription of rine. As regards the form of cartridac, I believe the military authorities would be onls too glad to shoot with the conical cartridgo that Captain Javics has shown us, but there are difficulties in the way of usanufacture. I remember that these cartridges wero uiade by Westles lichards and Co. for Sir IIenrs Halford, who fired a 0.10 bore 3 Ietford rille so chanbered at Wimbleclon. As regards tho burrel, To lare this scmarbablo fact, that according to the crperience of the most skilled shots in the world at Winbledon, during the last fiftecn or sixteen ycars one system of rilling, the J[etford, lias cone to the front, and has driven the other 65stems of rifling out of the ficld. AIen are not foolish enougli to pas licars cutrance fees to shoot with rifles that won't carry straight; they ulriags go in for the rido that gires the most bullg'-ejes. Whenerer uny phenomenal shooting has been done it has been with tho IIetforil. As long ngo a:3 1566 thero was a competition at 2,000 yards with telescope riles at Grarcsend, when JIr. JIetford nud sir IIenry Halford betreen them swept the bo:rd. With a heary Jictford muzzle-loader, threc or four ycars ayo, Sir IIenrs IIalford, firing with the JIetford, $0 . \pm 0$ bore, with a taper cartridge befora inentioned, put ten ehots running into a small parallelogram at 2,000 yards, and beat the Finfield-J Inartiui hollow at that distance. 'The other day, as was etated in the "Times," at 1,000 sarts, Mrr. Gibbs, of Bristol, put 50 consceutirc shots into a i-fect circle, and 1 s of them into a 3-fect ringing bulls'-c5e. Eicery time the bulls'-esa was hit the bell rang, and could be heard a mile oft, so there could be no unistale ahout it. The nccuracy of this shooting was certifed by Sir Irenry IInlforl in a letter to the "'Pincs." MTureorer," in 18SO ome excellent elooting was clone with a 0.1 ; borc Mretford-3lartini, by Jajor Swecting, in the eccond long.range mateh that took place between Birmingliau and London. I was witness to that, und he put 27 consccutire shote, at 800,900 , and 1,000 yards, into a parsllelorram of 2 feet ligh by 4 feet broad. I hare also been informed that the German Gorernment, aficr a long ecrics of official experiments, lare como to the conclusion that the best form of grooring for a military rille is a circular groore as shallow as possible, and no sharp corners, in sisort tho Mfetford systew. It is rery curious indecd to fud that in the fnce of these facts the Enficld duthorities hare adopted the rerersed ratchet, which gires the longer slope as the 
driring cdge. Colonel Arbuthoot stated to ne that the object of rerersing the ratchet was that the bullet might be driren in against the short slope to clear out the fouling. I submitted this statement to a stilled espert, who declarel that the statement was so absurdls grotesque lie conld not bcliere it nas crer marte. I challenge Colonel Arbuthnot, in the presence of this meeting, to gire a tangible cxplnadion for rerersing the ratehct. Attention lias been drann by the gallont lecturer to the nuatter of smokeless poxiler. I beg to be allowed to inention that about a month ago I fired at 800,900 , and 1,000 Jards with a Iretford rifle, at Wimbledon, with fair success, and at 800 yards I put firc consecutire shots into an eleration of a foot, and this was done with a smoleless powder, tho inrention of $u$ German. I was told that at 300 Jarils the sanole was invisible; it scened to be rapour rather than smoke, for it ranished in the air. I aiso have with me a speciinen of the French explosire, of which we hare recently heard so much, known as melinite; if jou would like to rec epecineug of thesc poirders Qtashed, I shall be happy to show you; there is not the slightest danger. I saw in last Saturday's "Engincering" a statement that the Germang, jut on their mettle by the experiments of the French in blowing up a fort, had conducted some similar trials, and that the German powder had beaten the French porder. I haro also got a small pinch of that, but not crough to makc an crlibition of.

Jajor JIACrrsie, R.A.: I rag glad to hear Captain Jnmes draw attention to the subject of flat trajectories, because they arc most ciscntial in crabling hits to be inade, whether at a long or a slort range. If the trajectories of the present rifles had been inserted in the diagrams beforo us, we should eze that the advantage which is anticipated from the newi"urms is simply following in the same direction as the progres 3 which has already been made, and the present Scrrice rille ngain lias a Hatter trajectory than that of a fer ycars ngo; there cannot be a doubt twat grealer facility of hitting ans target is thus gained; in other worda, the more nearls the tmjectory approaches a st raight line the less dificulty there is in adjusting the sight of your rille, nnd errors in cetinating the range become of less innortance. $A$ flat trajectory in sunall-arm fire at practical ranges can only be obtained by tho usc of a Emall borc. 'Tho net Enfield. Ilartini rife has nuade some adrance in diminishing the size of the bore, but there is still room for further progress in this elirection. I belicre fouling is apt to occur with snall bores, and the suggestion of a compound bullet of lead jacketed with stecl certainly appears to descrse the rers greatest attention; the compressing of the pouder in the cartridge also scems to be an important nutter, as it crables a largcr cliarge to be placed in the samo space. In order that recoil mas not be excessire the increased muzzle relocity reguired for tho flat trajectory of a modera rifle necessitates a lighter bullet than bas been prerionsls cmplojed; it mas be enid that with a bullet of less weight you would not hare such etopping pormer as before, but in order to attain a flat trajectory you must hare high relocity, and you can then afford to sacrifec weighit of bullet, sinee the measure of the blow indicted on striking depends on reight and relocity. The Enficld-Minartini rifle is doubtless a great adrance on what we hare alreads, but futurc progrces mas certainly be marlo by increasing the muzzle relocity and further fattening the trajectory with a liminution of bore and weiglit of bullet, and probably an increasc of the porder charge.

Coloriel A nntrnsor, R.A.: I thinl, Sir, the subject to which the lecturer has drawn attention, namely, the reduction of the bore of the barrel, is one to which too unuel consideration cannot be giren. Illicre is no doubt, as Mnjor Mackiolay lias just Eaid, that the Faficld.Jrartini is a step in the right direction; but wo might go still furtber, and that in the direction in which we are moring will be found to be the correct one as time adrances; but I do not think that we are as jet eufficiently adranced in our lnowledge to junn all of a sudden to a rcry much smaller bore. There are other considerations besides hatness of trajectors which hare to be talen into account whicn jou come to the reduction of the bore of the rifle barrel-und of these the question of weight is no doubt one of grent importanec. 'The bore of the barrel cannot be greatly reduccd without incressing jts weiglt, because if the barrel is Ieft of the same dimensions as at present, it must of necessity be greatly thiclened, whereas if the ontside diameter of the barrel is reduced it is made too weal to etand the rough usage it is likels to be subjected to; therefore in considering the 
reduction of the bore sou cannot eliminate the question of ncight. But, apart from that, flatness of trajectors is not quite so all-inuportant 23 appears b5 looking at the diagrams before sou. It is perfectly true that with $\mathrm{a}$ bore 0.3 in diameter sou hare a trajectors at 500 sards of about 5 feet + inches, and with tho Finficld. Hartini, with a bore of 0.4 , you have a trajectory at 500 yards of 6 feet 6 inchesahout a foot higher. Bul thint is not quite the wro to look at it. 'The Finfielil. Iartini is sighted true for 150 gards. Firing at thiat runge the bullet will trasel 350 sards before it strikes the ground; and during the whole of that range the eneay is under fire. There is no ilraming to show that, but that is the ense. Niow, by reducing jour trajectory 10.4 fcct 6 inchea, it will astonish many of sou to hear that a bullet will only trurel abont 350 or $\mathbf{3 9 0}$ yards before striking the ground ; so that the only gain in range is the difference bet ween 350 and 100 sards-sou only gain the range of 50 yards by the ertrit lowness of the trijectors. Again, another point must always be borne in mind, namely, that the height of the trajectors is rery deceptire. You talk of a \& fece 6 inch, 5 fect $G$ incli, or $G$ fect 6 incli trajectory: that means the beight of the trajectors abore the line of sight. If the man is standing up the bullet is + fect 6 inclics from the ground at starting; therefore if rou take a trajectors of 5 feet 6 inclies, thic bullet at its highest point is 10 feet from the ground. If the firer kncels the rifle is still 3 fect from the grouvd, and therefore the highest point of the trajectory will be 8 fect 6 incless from the ground, and therefore the bullet will be orer a man's lie:ad for a considerable part of its lipht. Thast is apt to be orerlooked. A rain, the difference in heiglit of trajectory between barrels laring bores of 0.4 and 0.3 is vers immaterial. It 300 sards an infantrs soldier would be corered by both; at 500 sards by neither, and, therefore, the gain from 0.15 to 0.1 is incinitels greater than the gain from 0.4 to 0.3 . But I aw quito prepared to admit that we shall probably come to a smaller bore, in the way we are adrancing. I think the adrantage of a small bore is that the weight of the ammunition ean be reduced, and thereforo the soldier will bo nblo to earry moro rounds than at present. In a magazine rifle that is a consideration which will lasro to bo thcught of. Not that I think the magnzine rille will necess:urily bring about a larger espenditure of ammunition. I think, on the other hand, it will mako the unan husband his aumunition; lecenuse, now, a man loads when lie sees his encing, aud fires as far off us he c'an in orler to get 35 neany shots into him as possible while he is adrancing; but if he is certain that he will be uble to firc sir slouts without haring to reload, I think the tendency would bo that he would husband his amenunition, and not begin to fire till lie knew he could hit his man, and get off the sir shots before the man could reach him. I think the tentency will thercfore be rather to lusband ammunition than to crpend it. There hare been inang syiteins of mngazine rifles under consideration this nftcrnoon, but it is quite unnecessars for me to enter into any details with regard to then, secing that Captain Jawes has rery thoroughly exhansted the subject. I think that the two ssstems that wo aro about to issuo for trial will innterially clcar the air und cuable us to arrire at a system which will be the best in Europe. We are not behiul other nations at present with the exception of Germans, for no other conutry has adopted a magazine rille ns yet definitely; I wean thes baro none made; some nations hare only just completed their experiments, while others are still experimenting; and no other nation, perhaps, with tho cxception of Switzerland, can-realls proride its Army with a mngazine arm-alwars escepting Germany. I hope, therefore, wo shall be quito prepared for any energencr whichl mas liappen, and ready to are as quichly as inost European countries can with a magazine rifle.

Coloncl LOSSDALE IIIIE: Thicre is a certain class of members who attend these lectures, and who are always couspicuous by their silenco; and thes aro the rery inembers to whom, in this Institute, one of the objects of which is supposed to be to draw out pructical information, we should most of all wish to listen. I refer to thoso Generals, Colonels, and other Ofieers who have had in the ficld practical experience of the fire discipline of the British soldier. It is very interesting no donbt to know whether the bolt gun is right or irrong-whether the stecl-corered bullet or the copper-corered bullet is the right thing to atlopt; but I do not think we care so much about that after all. The burning question for the British Army is how far we can lrust the British soldicr in the use of his firearn-and therefore 
What form of magazine rille, frum the point of firo control, should be put into his hand3. Is there any Officer lice with the experience of Majuba and Egypt who would dare trust in tho liands of the lbritish soldier anj ono of those magaine rifles on tho tablo? My friend Captain Janies has passerl orer in a few words the question of the "remorable" znagazine or the "Gised" magazine. I was under the impression that the remorable mamazine was the solc means by which you could control tho firo of tho Britisls zoldicr. Tho Oficer corumanding a company could then at once Ece whether the magazines were on or not, and thercfore for the British soldier, with his weak fire discipline, the remorable magazine is the only magnzine that will be full when he arrires at what tactical unthorities consilder the point where it must be used, at 450 or 500 jards from tho object. We should be, I nm sure, rers grateful to ans Odicers present if thes would give us the result of their experience, and tell us how, tactically and otherwise, they would conduct the magnzine fire of the British soldier.

Nore. - IVith reference to reinarkg made subsequentls in the discussion, I may s2y that the supervision must, in order to be effectire, be easy. Whether a bolt stopping the action of the magazine is in a purticular position or not can hardly be necertained in the heat of battle. The presence of a magazine on the rifle is discernible at a dist:ance. The argument that remorable magnzines would be lost or thrown uras lias been applied to remorable cutreuching tools and remorable iron rations, and get somehow or other they are nuw regaried as absolute necessaries in molern war.-L. $\Lambda$. II.

Colonel Frasen, K.F.: I had not intended to say anything on tho subject. I confess I do not agree with Colonel Hale about the remorable magazine. Hy riew i3, that if gou hare angthing in the nature of an arm in zwo parts, that is, to go throught the contingencics of fylting, the probability is tlust the remorable mugnzine will not be in its place at the critical moment; for which moment alous we are justified in encrificing the simplicity of the single-loader. I do not think it is possible to haro things too simple for wur. That is the result of what I hare noticed on the fer ocessions that I hare becu present in action, sull I au suro that if the soldier has to fumble for the morable magazine in order to fis it on lis rifle at any suprene mourent, the armangement will not work. I liare seen troopy with repeaters in action in the war of 1877 , and I do not recullect any special dificulty us to their ammunition. Control of fire is impossible during the crisis, for the salie of which a repeater is being introduced. At other times, it does not. depend on the nrm, but on discipline in all ranks and on coolheadedness of race, supplemented by training. Jay I say how cntircly I agree with Captain James, and how wamnly I support him in the desire he has expressed thant we should urrire at something like finality about the bore, so as to lase the lightest ammunition that is thoroughls efficient. Colonel Arbuthnot has told us that wo are coming presentls but not now to a simaller bore than the 0.4 . The 0.1 bore mas be the best in the world for the present, but I think before we commit ourselves for the next 15 jears definitcls to that size of bore, it would be verg desirable indecd that the question should be further threshed out, in riew of the results alrends obtained with smaller bores and the crident tendency on the Contineut. Jias I ask Cuptain Jumes whether stcol-corerext bullets liare orer becu tried on the carcases of horses?

Captsin Jaxr:3: Fes, they lare.

Colonel Fras: B : With what result? Do thes flatten or not?

Captain JגXEs: Thacy do not datten.

Colonel Frsser : Then I do not think that thes will hàre the efiect of the lead bullet. I belicro the effect of the Icad bullet is due to its Aattening like a mush. room, and so producing a larger wound. This cspansion, and the consequent shock of the sudden stopp:tgo of the bullet, ruries with the relocity. It is slight with the IIartini, considerable with the $G$ ras and express rifles, und more so with tho smaller borcs yet tried, when they hare still higher relocitics. The dearructire efficiency of rers small bores is, I think, secured by this fact, and nould be lost with stcel-corered or rers hinel bullets. In the Trans rad War about 50 per cent. of our men struck with bullets died at the time or in hospital $\rightarrow$ a percentage greatly in excess of wint liaz oceurred in other wars. The pereentage of woundect to 
billed is usuall, I beliere, something like 5 to 1 , but wlicre the Bocrs shot with express rifles, I think about crery secoud man struck died from the effects.

Admiral SrLwT: : Mas I claim to sus a fer words'on the subject of the cartridge? First, the aescrtion by Captain James that thio flatness of trajectory, the high velocity and other qualities to which he attaches great importance cannot be obtainel but in one single was, that is to say, by resorting to a small borc. Now I think on that point. we lave not attempterl to eshaust the subjest Jet. On the contrary, all that we do know shows us that by the regulation of the grains of powder, of the naturo of the porrder, and in other wass, wo can obtain a much greater relocits than has crer been attained bs the usc of the smallest bore, and without sesorting to anj other rifle or calibre than that which wo possnss at present. The relocity of the Martini-Irenry has been raiecd by such means by Mr. Nordenfelt with the same reight of pasder, with tho same black poirder, no ner powder nt all, from 1,350 feet per eccond to 1,700 fect. If that can be done, that is tho dircetion in which wo should trs firet to exhaust tho csperinents. No good progress, no sound progres3, can crer be mado by riolating any of the first principles of physies, and you do violate one of the first principles of physics rben jou resort to a bullet composed of a metal of a lighter specifie grarity than lead. I do not carc for whint reason sou do so. Those reasons may disnppear, but the master fact, the plissical law, can nerer dieappcar and must always remain, and if sou go into compromizes with it, jou are sure to get a result which will crentually falsify itsclf. We hare not yet exhausted the question of fouling rilles which has brought sou to that decision in some measure of the small bore: we liare not set exhausted that rhich was long ago brought before us so well bs Captain O'Ilea, taking away the riding altogether through the greater part of the barrel. We only know that it did gire us a much higher relocity and a perfectls flat trajectors at a long distance, in what was then considered an obsolete riffe. IThy not carry out that experiment, which might casils be done, before jou decide on a ncr dieparture? You may fire a lnitting necdle, if as was shown by Whitworth you increase the pitch of the rifling with a rers llat trajectory and a high relocit5, but tho qucation is, what effect will it.produce at long ranges, and where will it go after striling the ground ? Still greater is the question, are jou prepared to recommend tro natures of ammunition in the ficld, one for machine-guns and one for the infantry rifle, or nre sou to fire knitting necdles out of machine-guns? These things ought to bo colrel first, and it is therefore that questions conecrning the rifle in any way whaterer ought to be left aside until you hase decided what projectilo sou would use, with what chargo of what powder you will drire it, and what case you wish to put that charge and bullet in. The difference between tho use of the ordinary cartridgo and a long and fine projectile is, that with the long projectile sou must male a long cartridge, and therebry you introduce difficultics as to the brecel action requircd for that cartridge. You then resort to the conical cartridge, but hare you ectiled what quantity of powder is necessars, or what is to be the nature and length of the cartridge? The cartridgo should not be longer than two inches, including the poirder nnd tho bullet, and if you make it three or four inches long, son immediately get into a scrics of difficultics. Then, again, do gou wish to hare compressed porder or melinitc, which I strongly suspect of being sonetling reT near an old discorery of Mr. Rerelly's, which was called sugar gunpowder, made of prussinte of potash, chloride of potash and sugar, which does not gire any emoke, which is white, and girce rers high results, but it docs gire also this, which I beg sou to remember, that whenerer you get no smoko jou are making carbonic acid, and you may also be making nitrous or bjdrochloric nitrous acid, and these are tho most corrosire things jou can possibly nut into a rife. It will crentusily, eren though jou mas clean jour rile as thoroughly as possible, produce rouglnese of barrel, and sou ought to look into this question long before you decide that nelinite, becauso it produces certain effects, is therefore the best powder. I ndmire rery much a great many of the rilles that Captain James has shown us, but nt the same time I hare a rers strong fecling that until you hare decided the quection of the cartridgo nad tho hullet, it is no uso talking about tho rifle. Wo inight haro to change it all, becauso we had a new cartridge to deal with, and wo should then wish to place it in a different part of tho rile. I know that Captain 
James is verg much with me in my contention that you have not exhatasted yet tho question of getting rid of uacless weights. It hus been pointed oul that a certain rifle wcights 11 lbs.: Lare gou got rid of all the uscless wood? What is tho uso of thint rood? Cannot you liavo an cqually rcsilient bods giving cqual protectiou from the beat developed by the firing, without a piece of wood? Is the wood a necessity? It is 2 rers scrious maticr, and when you tako array cren $2 \mathrm{lbs}$. of it, that gires jou 20 cartridges without an increased weight of ritlo; 20 moro cartridges carried in the arm econounized from its uscless weight." It is in these things thut we should make real prorress, and if the Coamultce rould determine to tule the first question into consideration first of all, and not the last frst, I should beliere that sone solid progress, progress which was not likely to require repudia. tion, would be made; but at present we are going on in the direction which must necesearily land us in a reopening of the whole question within a very few jears' tine, and another expenditure of money will then be needed.

Aduiral liors : I rise to malic onc or tro obscriations bearing on the maral part of this question. I belicre it to bo a fact that wo in the Nary requiro a magazino or repeating rile cren inore than thes do in the land Serrices. With us it is an aboolute necessity. In these days of fast torpeclo-boats and ships passing each other at rers higls specds, in rery rapid rile fre is most important, and it is equally important that we sliould hare it rithout further delas. One great objection to magazine arnes which we aflont are free from is that our supply of amumuition is reads to hand. Our small-nrm magazines are so near that thero is no difficults in regard to the supply and expenditure of ammunition. Iraring been connected with this magazine arm question some timu ago, is uy crcuse for offering an opinion. I would obserre that the rille I appreciate most amongst those that we hare seen here is the Austrian, for tho simple reasun that the cartrilges are supplied in a detached magazine; the firer has not to fumble about to fill n inagazine, pcrhaps, in action, but puts the packet itself ready filled into his rifle, and when it is empty and dowe with, away it gocs. There mas be an objection to the cost, but I think the crtra cost is emall now, and wight still be reduecd. Whaterer principle of nagazine rifle unay bo anprover, my rceonnecodation would be that it should hase a contrirance in rhich the cartridges could be stowed, supplied, and used in the rifle without having to fill unother nagazine from it, or to carry auother articlo of equipwent in the sibpe of a metal case. With reference to the stopping power of the small-bore rille, I lo not Ece that tho argument Captain James cupploys is quito sound when he eass that a small-bore bullet will, "striting lwalf way down the femur, go througlt and split it up into the hip joint." It is all a question of comparison. If a enall bullet does this at a certain distance, it is perfectls clear a hearicr bullet rill do the eame at a considerably grcater distance. Ifay 1 asl one question with resject to magazine rilles? If in ans rifle that Captain James is cognizant of, tho action of loading is done with the left liand by a slide underneath the barrel, so that tho finger is neres remored from the trigger nor the cro from the sights - xhen; in fact, the whole operation of estructing and londing is performed by a sliding block underneath the burrel.

Captain 1'. H. CoLosid, R.N.: I mar, perhap3, uscfully confirm what Admiral Boys has sail in reference to the ralue of the magazine ritle for naval purposc3, bs the case of the fight between the French and German ships, the "Bouret." and "Metcor," during the Franco.Gemuan W'nr, in the West Indics. The two ships closed, the one cindcarourcl to ram, and the other to aroid the ram, aud there was conoiclcrable ride fire in the fow moments of pussing. Ficarly the whole of the loss took place from the rine fire at that iustant. There was a thought which came into my uind when I was presiding orer the Magazine Gun Committec, seren or eight scars ago, and when wo had the carlicst forms of magazino ritles before us. 'That thouglit' lias been in miy unind erer einec, and it is rery inuch confirmed by whint the lectures and others bare stated to-day. It is that cren with your riflo without the mainaziuc your firing poircr is someriat alscad of jour supply powers, that you are likcly to bo short of anmunition as it stande, ard if what the lecturer has said be the truth, in opposition to what Coloncl Arbuthnot las stated, it rould appear that with tho nugazine jour firing powcr is going to be still more incresed without, so fir as I understand it, any steps being taken for incrcasing 
your supply. It appears to me, from that consideration of things, that you must be on the cre of some still greater and more complete change than is proposed at. present in rilles.

Licutcnant T'oprer: I wish to ask Cuptain James if he can tell us whether the dustrian soldier carrics all his ammunition in those little tin frames. If that is the case, I think that system bas a great adrantage which I bave not hearl wentioned, namely, that the anmunition is not eo likely to be lost out of the uran's pouch. The rille is loaded in a sceond, nnd ans one who has liad crperience of skirmishing knows how difficult it is to control the loss of ammunition whenerer the men lio down aud risc up. They generally lose screral loose cartridges from the reads pouch. It is a very great advantiaro to cnable the soldier to retain his anmumition. If thosc frames were adopted it scems to mo that a great clesl of the waste of ammunition would be sared, us it is much casicr to retain the ammurition in the frames than it is when loose in tho pouch, and I hope to sec that in the mugazino riflo adopted for our Scrviccz some such plinu for losuling and for currying tho ammunition will be prorided.

- General Juxis: I to a certain cstent agrec with what Coloucl Lonstlale Inale has saicl. It is absolutels esiential with the soldiers of the present clny that therw should be some powcr of restrsining tle mnoazine fire, and I think if they were prorisled with rifles with magazincs, it should be with such mamarincs as would be in some manucr stopped. I think Captain James wentioned oue in which there is a stop.

Captain JAYEs : Thlic inproved Lee.

Major-Gencral Duxse: Thiat I think is what etrikes me as the best, that is to sas, it would have the cffect of saring ammunition. 'There would be great diflicults in getting soldiers eren in a shan fight to ship or unship the magazines, and there is no doubt many morable magaziney would be lost; but if ne could hasc a riflo like the one Captain James has nentioucd, with stop on it so that it can be stoppech or started without being unshipped, I think tliat would both weet what Colunel Irale lias said, and also what has becn said by Colonel Fraser. I aw certainly in farour of some control orer the fire.

3Iajor LrsLIE: 'There is one matter I wish to draw attention to here, and whicle I shall be glad if the lecturer will kindly answer. IIe especially alluded to the Burton ribe, and condemned it - the inrentor I sce is bere present; but ho did not drat atfention to this particular fact, which $I$ hope lie will refer to in his reply, that the. Burton systcul is bs gravitation-that is to say that the bullct falls into its place. All other syatens introduee spriniz3 which are rers libely to get out of order, but tho Burton acts by graritation. I think the strongcst argument that can bo adduced agninst the Burton is that it is unsightly. In warfare you only want to uso the magazine when the cnems is close to you, and then the rsthetic argument is not of much consequence. It may be unsightly, but I deny that it is not efficient.

The Chatrarax: Ladies and fentlemen, I shall not delay yon long. So far as the rcmarks about the mechanieal purt of the rifle are concerned, I agne with 1 deniral Selwrn that we ought to hare some point from which we are lo start. Do we want the riflo for accuracs of fire or for flatness of trajectory, or the bullet for lightness or dendly cffcet? Wr hear that experiments ane now going on at linfield, and Colonel Arbuthnot tells us lie thinks he is on the rodd to reduciing the bore; but it seems to mo that after the breceh-loading rille bas been in use so long, with all Europe trjing to intent the best variety of it, wo should hare by this time known absolutely the best rifle, the best morle of rifling, and the best inctal to wale the bullct of and to corcr it with. Howcrer, thongh we haro not masde our sclcction, the Continental Great Powers hare done so: though it is likels the power of conrerting their respectiro arms into the drew magazino rifle lass Jiad something to say to the choiees that they lare respectively made. I will therefore dismiss this purt of the subfect bj assuming tlast our inrctstors will be succcssful in producing a perfect magazine arm for wilitary purposes. We will grant the rille as found: wo vill assume. it is a handy well-balanecl arn- not too heary for the soldier, with a Dit trajectory, properly rifled; with a bullet unale of the right weiglit and material, and the porrier right in quantity and quality; nnel, when wo linso got all these things, we hare not done then lalf our task, for we liare to prorido the man to uso 
this periect arm. It is of no uso to put a rery delicate weapon into an unjlilful minn's lands - and it way bo really dangcrous to put a magazine rifle into tho hands of a man uuless he has been surels trained to be eparing of his ammunition. 'lihat will be aur great difficulty. One sentence of Captain James's lecture will show you the was in which these ecrious essentials aro dismissed. IIe says: "In the underbarrel forms of magazine rifles, it is not proposed to load the rille during tho heat of an action. It could be filled before going under fire, cut of from acting, and onls brought into use at the supreme noment." Norr, gentlemen, who is to be judgo of the supreme moment of a general action? There aro a great mans Odiccrs hero who hase been in general actions often enough, but they eaunot sas which is the supreme moment till the latter is orer. Let us picture to oursclies the prirate soldier with his magarine rile : be loads it up full of eartridges, and when ho sees the enemy coming at him las eags, "This is my supreme woment!" and fires of the whole of his store of cartridges. Twenty minutes afterwards he might esperience a supreiner moinent, and trenty minutes after that the supremest moment of all may counc, when, with his magazine emptr and nothing but his busonet to rcly upon, he mas, with his life piss thio penalty of not haring correctly recognized which was to bo his suprense ruonent. Granting, therefore, all that Colonel Arbutluat cau do, and tho liar Offec can do, the real difficulty we haro to fight is to find men who hare quick eges, stcully liands, and cool heads to use them. This morning when learing howe I happened to sec lying nuout a lecture which I had the honour of delirering on the 12th of $\Delta$ pril, $18 \%$, in this hall: it was on the brecch-loader, and in tho first yaragrapl of that lecture I defincd the tiro principal points for con. eideration connected with tho brecel-loader 25 - The formidable properties of the arm in attack and defence", and "The helplessness of the arm mben sliort of ammuni. tion." Jow are sce going to teach the soldier to husband his ammunition? It can onls be done (1) by impressing into liim the conrigtion that with a viagazine rifle, plenty of ammunitiou, and a cool head he is absoluteis unapproachable; (2) by making him responsible at the field-dass of peace serrice, that howerce hot the fire, he must always have ten, or certainly fire rounds in his posscssion, and, if possible, his magazine full; and when he has becn oo trained, moralls as to realize his porrer, avd phssically that he husbands his ammunition, there will be no danger in putting a magazinc arm in his hands, and he will be fit to uso it. Commanding Onicers, Idjutants, and Captrins must tesch the eoldicr that he must erpend hie rounds as he docs his elillings, and be careful of then. I do not think anjbody ean conccire a more pitiable ense than would be presented by two opposing lines in presenco of each other; one line being short of ammunition, and the other line haring their magazines full. Therefore, by whaterce means it is done in this country, it is absolutcly necessary that wiluen the prirate soldier is cnlisted tho first object should bo to train him to shoot, and the second should be to teach him to cconomize his round, as tho most ralunble possession he has; becuusc I nin perfeetly certain there can be no greater danger to the I3 ritish Army than to allow our men to go into action without that lind of training being preriously assurcd to them. We must recollect the men we get into the ranks are not life the men that Contincatal aations get bs conscription, two out of erers three of whom aro educated men. These are not tho material we get for our Ariny; thercforo we must mako our training such as to mect that danger; and cren when our men are eo trained the artion mas nerertlieless be so long, or the fire so hot, that pouches and nagazine aro alike in danger of exhaugtion, and we must arrange to proride a fresh supply of cartridges. For this purpose in our Scrrice we haro a reserro ammunition cart attached to the battalion; and I think we should on crery ocension make uee of that cart either by issuing a small supply of blank ansmunition to mcn, or by cngaging battalions for a considerable time so as to test our sjstcm for supplying thid ammunition to the troops. I think it would be a rerg grest adrantage if on crery field-day at $\mathbf{N d e r s h o t ~ o n e ~ o r ~ m o r e ~ b a t t a l i o n s ~ s h o u l d ~ r u n ~ o u t ~ o f ~}$ their ammunition simply in order to sce that our arrangements for aupplying fred ammunition are cfficient. The ammunition cart must bo made constant use of if re issue this new rille. It is nol giren to the troops because we want a quicker shooting rile than the breesh-loader: it is only giren for the moral effect, becauso it would not answcr our purpose to ecnd our troops arwed with our prescnt rifo 
amainst a cirilized enculy. With magazine arms our soldiers rould have a hind of inoral fecling that thes rerc armed as rell as the cncms, and this might qualify their ralue as soldiers. Therefore as it has becn decided to issue magazine rincs, we hare to train tho men in pesec-time, so that when thes go into action they shall beep their heuds cool nnd shall feel that with the best rifo and plenty of smmunition nothing ean come near them. If the British soldier can onls be trained to fecl that, he will bo carcful with his cartridges. I think the question of ammunition carts has not been balf cnough considered, and it is a question whether making the party in chargo of the rescre anmunition cart responsible that it communicate 3 with any part of tho battalious hearily cngagcd as to tbcir requirements in rezpect of ammunition, might not proride a double security againet this greater denger that the issue of the nagazine arin nans introduce.

Captain Jayes, in reply, said : I will deal first of all with Qeneral Braj's renarks. The kemington-Leo does not hold sis round, but only fire. Then he discusscd the question about practical and theoretical men, and he was of opinion that practical men would reserre their fire till 400 sards. "There were practical men, I belicre, at the battle of Grarelotte. The fire from St. I'rirat certainly rangcd orer 2,000 yards, and killed a rery fair number of Prussians at that rangc. 'Therefore, 1 think it would be diffeult in like circunstanecs to reserre jous fire till jou get within 100 yards. The Mrauser rifle I have shown you this afternoon is an entirely new arm, a new barrel, and a new arm altogether. The old arms bure not been altered into the Mauser repeater; new arms entirely haro been manufactured. General Bray thinks I should put the Schulhof first. I ain perfectly awarc of tho manj adrantages of the Schulhof; it is an esceedingly good rife, but I carefully atated at the beginning of my lecture I did not propose to absolutcly adrocate anj particular reapon, und I think you will agree with me tbat was the best position for me 23 lecturer to take up. Had I come down here as an adrocate of ans special or particular form of respon, you would vers justly hare said "Captain James has cone hero not to gire us a lecture on the general question but to forkard the particular wcapon of some special inrentor." I scarcely think thint would be beconing in ms position, as one who proposed to deal generally with the subject; therefore, whatercr may bo my own personal opinion of the Schulhof I should feel it wrong to hare come down here to adrocato that to the cxclusion of any other. Colonel Hope asked me about the $\frac{d^{2}}{20}$, whether that could not be reduecd to one. I should

like to sec it reduced eren lower were it possible, but if jou get it much lower than tro, the diffeults becomes so grcat of using it in the rifle, bccause you get such an enormously long projectile. Witl regard to the rifling, I mas sey rilles are now being made at inficld with the Enficld-IIartini bore-0\%, silled on the MIctford osstem. There is also a new form of rifling which gires rery yood results indecd, in fact, go far as the results show, this form is as good as the bietford. Now I will denl with onc or two points that Colonel Arbuthnot alluded to. Colonel Arbuth. wot's position is this: "A small-bore! Yes. I bclicro ne arc going in the direction of a rery muck smaller bore, but I do not mant to go there yet." That is just whero I differ from him. I rant to get to a final position as 8000 as we can. I eaid in a letter I wrote to the "Times" some months ago on this question, that I had suff. cicnt knowledgo of the Chancellor of the Exchequer to be quito sure that if wo screx out of him the nones for the new nrmament of the British soldier, wo are not likely to get a sircilar sun erery two or threc jears; hence when we settle on our rifle let us for goodncss' sako go as far as wo can ulong what is cridently tho path of progress. Now as to the lucight of the trajectors, of course crersbods lnows tho licights aro meusured from the straight line along which thes are plotted, orer the borizontal line. But Colonel A rbuthnot onitted one point, namely, that a large proportion of the firing would be delirered when the men were lying down, and con. sequently if you airn at the fect of the object, as tho German soldier is habitually taught to do, the trajectors is rers much more like that (pointing) than it would bo if the rille were held absolutely horizontal; and henco the real results more ncarly ap. prosimate to that-I allude to figures - than Colonel Arbuthnot implied. Horcoser, thero is another point. Esperiment shons distinctly, and I am perfectly sure anybody who has crer scen any firing knows it to be the case, when troops fire a rolles the 
ground is strucle rery often fairly closc to the rifle, and the bullets $5^{\circ}$ on pretty close to tho ground up to a distance bejond the object aimed at. When you get a rery flat shooting rille what jou do is you sweep the ground up to long ranges. It is perfectly possible to construct a rifle that elall, for practical eoldier purposes, only want one sigli! up to 700 sards; that is to say, that you shall sicep the ground up to about 700 yurrts. Alloring for differences in ain, which is a practical thing which is first of all workecl out by the Germans in lovg-range rifle crperiments, Jou

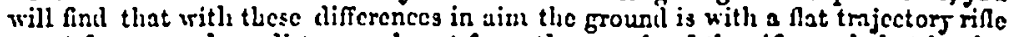
sircpt for a rers long distance, almost from the muzzle of the rifle, and that is whr tho Aat trajectors is such a.vers great object to tho eoldier; because, practically; taking into consideration low soldiers do actually fire, and the rariable aims that thes bare, jou do get the ground so thozoughly well smept up to long ranges with a dat trajectory ritlc. Coloncl Hale spole in farour of remorable magazines. Colonel IInle and I are rery old friends, though wo hare before differed liere on tactical subjects, so that I am rcally not surpriscd to find ho again differs froun me, ns he docs from moat lecturers in this Institution. The detachable magazine has been tried in smerica, and it was found the nest das that a large number of detachable magazines liad becn left behind. 'The result would be that often when the soldicr, ercis s lighlyly-trained man, caln snd capablo of attaching the magiaine, was required to do so lie would be in this unfortunate position-that lie had not got it. Like the French Allmiral who said he had a hundred ressons why he could not tiro a salute, the first being that lic had not ans powder, so would it be with the soldier in the caso of the detachable magazinc, ho would liaso detached it once for all, and he would not be able to use it when the proper morwent came. J)etachable magazines may be lost, and when it is the neapon is no longer a repeater. Moreorer, how is the Ofiecr practically to ascertain under firo whether the soldier has afired his magazine or not? Such theoretically finc distiuctions sarour unuch more of the study than of practical esperience of war. Be certaiu of one thing, there will como a time in crers fight when no power will bo nble to prerent the eoldier using his magazine, whether fixch or detachable, and do not atterpt to intraluce an inedicient weapon simply for an illusory and theorctical adrantage. How can jou $t$ cll in action when one out of ten soldiers lias fised his nagazine $\gamma$ jou cannot. cren be certain ut target prectice of thic cxact number of rounds cach man fircs in open order, nuch less ean you under heary fire when all jour energies are taken in ratching your men, in looking to the efrect of your fire, in obscrring tho morements of the enemy, nfford to derote your nttention to ascertaining whether cach indiridual Tomms Atlins lans or has not nttached something to the underneath portion of his rific. Adnuiral Selwyn stated what I believe to bo the right ras of regarding a rile. In malking a rilo what liare jou to deal with? First of all yon Jiaro to deal with the bullet. Luet us start with what the bullet is. What do jou want it to do? To gire a flit trajectory. You want, therefore, a high relocity. 'rlien sec what powder you require to obtain this, what Eort of cric sou are to put it in. What rifing do sou want for the barrel, and then, lastly, coines the breech and the magazinc. Admiral Sclwyn sags you cannot haro a cartrilge-case with a bullet so that the two together aro louger than 2 incless. Fow I must point out to the audience that the wholo of Europe is on the other side; personally, I am on the side of Furope. Adimiral Selurgn ulso says you riolato a physical law by using another metal than lead for the bullets. I an prepared to riolate all sdmiral Selngn's Eo-called laws, but which we must remember are only his personal riers about the laws, if $I$ get what $I$ consider a better bullet. ' I must drat altention to another point. Ife statch that if jou usc certain ponder jou will injuro jour riflo rers much: That is perfectly true, but it docs not follow that the whito porder rrould produce nitrous acid. It docs not follon that there aro eng nitrates in the composition. There ving be clllorates, but it rould be an extraordinars chemicsl process to unake nitrates out of chlorates. Mrajor Leslic objected to my remarks stout tho Burton riffe, and said as far as he understood what I liad said that I did not like the Burton rife bocause it did not please $\mathrm{ms}$ xsthetic feclings. Well, I candidly admil I nm rers xsthetic. I admirc crergthing that is beautiful in nnturo nul in art, whether it be in the surrounding ecenery or cren in the magazine rille. - But I renturo to dran attention to this point, that I never used the word asthictic, 
and I nerce said angthing in ns lecture rlich would lead angbods who I think brings an unbiased judgment to bear upon tho subject to belicre that I objected to the Burton rifle because it ras not beautiful in form. If it is a rifle that outed our requircments $I$ should be tho first person to adrocate its ndoption. I stated that $X$ did not adrocate any particular form. I sas onee wore, a manazino on tho sido is not as well suited for the soldier as a magazino underncath. I think tho Burton in many respects an admimblo rifle, but $I$ do think the arrangement of the magazino on the side is not as good for tho soldicr as it is when undernentl. I declino to enter into ans argument as to mechanical arrangement, becauso I do not think a lecturo theatre is the proper place for it. I can only once more $8: a y$, I do not think it is so good as other forms of mag:izine, but I certiinly did not condemn it in stroug terms, because I beliere I spole in the most guarded manner about it. Admiral Joys asked me if I was aware of any furm of magazine rille which rooked by ineans of the Jeft hand, so that the right linnd did not get talen away from tho trigger. There is a form of rille for a small cartridgc; but when jou come to a long cartridge, as you must bave, it is quite impossible to use that 85stem because the trarel of the left arm would be so great. Licutenant Tupper askel me whether the ammunition of the Austrian rifle is almars bept in these cases. YCs, it i3. As I etnted, it is serred out to the soldier in troceses put together and wrapped round with paper. That is the way that the ten rounds are issued to the Austrian soldier, so that he always has his cartridges in a form out of which they cannot casils turable. And now one word about mhat Mrajor-Gencral Clive said in lis rcmarks. I ain perfectly certain of this, that whaterer system of rifle jou hare, whether a magazinc or an ordinary brecch-loading rife, it is no gool laring the most perfect one in the world unless the men into whose hands you place it are themselres properly trained. I do venture to sas one thing most distinetly, and I am perfectly certain a large number of Oficers in this theatro must agrec with me, that the present practical training of the Britislt infantry soldier is by no means on an cqual footing with tbat of the forcign soldicr, and it has by no neans renched tho lerel which it must reach if the British soldicr is to go into the feld as thoroughly conrersant with his duties and as able to carrs them out ns is at the present moment the German. General Clire mentioned ono point on which I personally have a rers strong fecling: ho said the Colonels and Adjutants, and Captains must look to the training; but he must go one step lomer, he inust go to tho Licutenants. Erery Eingle Offecr who lends hiz men into action must fully know beforehand what is required of him. He must hare that training which practice in peace under conditions of war alone can girc, and for nnyone to imagine that troops who nay bo cxcellent at marching past, who may drill like a stono wall, aro tactically fit to meet a properly trained foc, is a delusion which will only be dono amny with at the price of defeat and elaughter on the battle-ficld. This is a question to which the attention of all tho bigher authorities in the A rmy must be called. It is useless for us to imagine at tho present moment that our troops as they are are fit to meet any foreign foe, becsuso they are not trained on any system cqual to that of tho French, Ccrman, Austrian, or Russian, in fact, not equal to tho system of ans sation who practicalls know's what war means.

Mrajor-General Desse: 'Ibe lecturer haring the last word, it is impossible for me now to repls to the unexpected remarlis on the want of proper training amongst. our men, but coming from our principal School of Instruction at Nddershot, I must protest against much that has been said against the waj we prepare our troops for war, and I beg tbis inceting to beliere that we are not a quarter as bad as we hare been painted. (A pplausc.)

A roto of thanks to Captain Jnmes for his intcresting lecture ras then carried unanimously. 







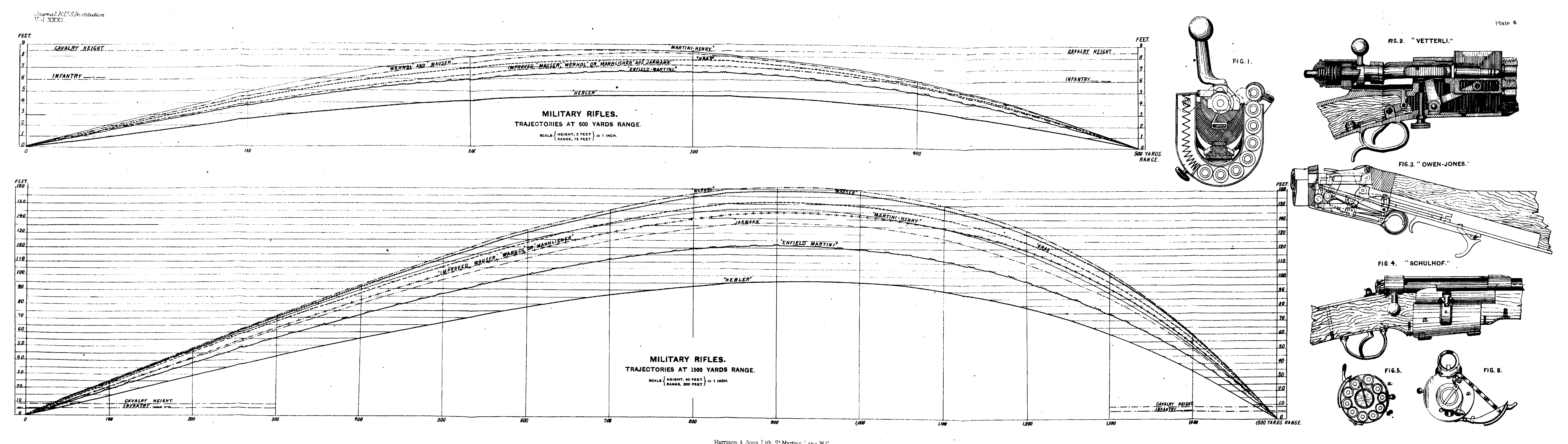




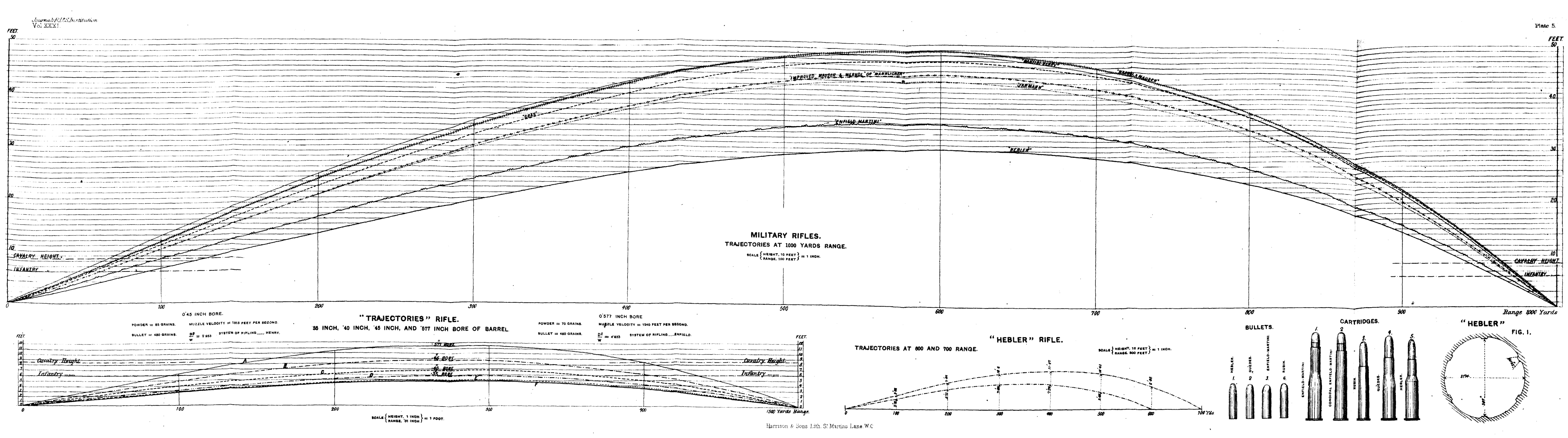

